\title{
PEMETAAN LOKASI KELUARGA PENERIMA MANFAAT PKH DI KECAMATAN PRAYA TENGAH MENGUNAKAN EXTENTION GEOPROCESSING
}

\author{
${ }^{1}$ Sofiansyah Fadli, ${ }^{2}$ Fitri Rohyatul Aini \\ Teknik Informatika, STMIK Lombok \\ Jln. Basuki Rahmat No.105 Praya Lombok Tengah 83511 \\ ${ }^{1}$ sofiansyah182@gmail.com, 2fitrirohyatul93@gmail.com
}

\begin{abstract}
Based on data from UPPKH sub-district of Central Praya Year in 2017. The number of beneficiaries from the Government Program namely the Program Family expectations (PKH) and Beneficiary Families (KPM) is 3,425 which are spread throughout the villages in the Central Praya. The existence of the problems and constraints that have emerged is the difficulty the other escorts who are outside of the town would like to know the location and development of recipient PKH KPM. Extention Geoprocessing is a tool for processing spatial data in ArcView. The use of extension geoprocessing on the geographic information syste is one tool that can be used to assist in analyzing the condition and whereabouts of beneficiaries of government programs, especially the PKH KPM Program, especially in the Central Praya sub-district.

The method used in analyzing data is the model SPIRAL method, the programming language used is PHP / MapScript, and criteria used are sourced from BPS. With the building of a geographic information system mapping the PKH KPM location, the community and the government will find it easier to know the development of poverty and can facilitate outside sub-district facilitators to find the location of PKH KPM in the central Praya sub-district.
\end{abstract}

Keywords: Extention Geoprocessing, Family beneficiaries of the PKH, SPIRAL Method, SIG

\begin{abstract}
Abstrak
Berdasarkan data dari UPPKH Kecamatan Praya Tengah Tahun 2017. Jumlah penerima mafaat dari Program Pemerintah yakni Program Keluarga Harapan (PKH) dan Keluarga Penerima Manfaat (KPM) adalah 3.425 yang tersebar di seluruh Desa di Kecamatan Praya Tengah. Adanya persoalan dan kendala yang muncul adalah sulitnya para pendamping lain yang berada diluar kecamatan yang ingin mengetahui lokasi dan perkembangan penerima PKH KPM. Extention Geoprocessing adalah alat bantu dalam melakukan processing data spasial dalam ArcView. Penggunaan extention geoprocessing pada sistem informasi geografis merupakan salah satu alat yang dapat dipakai untuk membantu dalam menganalisa kondisi dan keberadaan penerima bantuan dari program pemerintah khususnya Program PKH KPM terutama di daerah kecamatan Praya Tengah.

Metode yang digunakan dalam menganalisa data adalah metode model SPIRAL, bahasa pemrograman yang digunakan adalah PHP/MapScript, dan kriteria-kriteria nilai yang digunakan bersumber dari BPS. Dengan dibangunnya suatu sistem informasi geografis pemetaan lokasi PKH KPM ini, masyarakat dan pemerintah akan lebih mudah dalam mengetahui perkembangan kemiskinan dan dapat mempermudah pendamping luar kecamatan menemukan lokasi PKH KPM yang berada di kecamatan praya tengah.
\end{abstract}

Kata kunci : Extention Geoprocessing, Keluarga Penerima Manfaat PKH, SIG. Metode SPIRAL, SIG

\section{Pendahuluan}

Berdasarkan data dari UPPKH Kecamatan Praya Tengah Tahun 2017. Jumlah penerima mafaat dari Program Pemerintah yakni Program Keluarga Harapan (PKH) adalah 3.425 Keluarga Penerima Manfaat( KPM) yang tersebar di seluruh Desa di Kecamatan Praya Tengah. Angka ini meningkat dari tahun 2011 yaitu 1.181 KPM. Pertambahan jumlah penerima mamfaat tersebut dikarenakan pemerintah menggalakan penerima bantuan PKH ini harus mencapai 10 juta KPM pada Tahun 2018 diseluruh Indonesia. 
Persoalan dan kendala yang kemudian muncul adalah sulitnya para pendamping lain yang berada diluar kecamatan, insatansi pemerintahan seperti dinas sosial, dinas kesehatan dan dinas pendidikan dan pihak pihak yang ingin mengetahui lokasi dan perkembangan penerima program keluarga harapan yang berada di dimasing masing daerah.

Sistem Informasi Geografis merupakan salah satu alat yang dapat dipakai untuk membantu dalam menganalisa kondisi dan keberadaan penerima bantuan dari program pemerintah khususnya Program Keluarga Harapan atau yang sering disebut PKH terutama di daerah kecamatan Praya Tengah. GIS juga dapat menyampaikan informasi dalam bentuk peta tematik sehingga kondisi suatu daerah terhadap kemiskinan dapat disajikan dalam bentuk visualisasi peta tematik dan dapat mempermudah user dalam memahami informasi yang disampaikan.

Dengan rancangan sistem yang kami sajikan ini, di harapkan user dapat mengakses informasi penerima bantuan program pemerintah dalam hal ini penerima bantuan PKH di Kecamatan Praya Tengah secara langsung melalui internet. Sistem ini didesain berbasiskan web dan terhubung dengan jaringan internet. Dengan demikian datanya dapat dilihat dan ditampilkan dimana saja dan kapan saja (realtime) dibutuhkan secara cepat.

\section{Tinjuan Pustaka}

\section{A. Penelitian Terkait}

Penelitian yang dilakukan oleh (Wijaya dkk, 2018) dengan judul "Sistem Informasi Geografis Dalam Pemetaan Lahan Gambut di Kabupaten Musi Banyu asin". Sistem ini dibangun bertujuan untuk menjaga kelestarian lahan gambut adalah tersedianya data dan informasi tentang kondisi lahan gambut yang komprehensif dan terbaru yang bisa diakses oleh pihak yang berkepentngan dengan kondisi lahan gambut.

Penelitian yang dilakukan oleh (Kristoko Dwi Hartomo dkk, 2016) memberikan kesumpulan Model Pemetaan Daerah Miskin Menggunakan Sistem Informasi Geografis sistem ni dibangun bertujuan untuk pemetaan daerah miskin menggunakan Sistem Informasi Geografis (SIG) berbasis web dan mampu merepresentasi data statistik menjadi informasi berupa visualisasi peta sehingga dapat mempermudah pembacaan data dan mengetahui sasaran hingga daerah termiskin. Addibi dkk (2015) menyimpulkan Sistem informasi geografis yang dapat membantu masyarakat untuk mengukur besarnya indikator identifikasi pangan di Kabupaten Madiun dan menentukan status ketahanan pangan untuk setiap Kecamatan di Kabupaten Madiun.

Penelitian yang dilakukan oleh (Abdul Nizam Faisal, 2016), dengan judul "Sistem Informasi Geografis Berbasis Web Untuk Penyebaran Fasilitas Umum di Kabupaten Klaten". Sistem ini bertujuan untuk membangun sistem informasi geografis yang memberikan informasi penyebaran fasilitas umum di kabupaten klaten.

Selain itu berdasarkan penelitian yang dilakukan oleh (Resti Lucyana, 2016), dengan judul "Sistem Informasi Geografis Untuk Pemetaan Pariwisata Kabupaten Pesisir Barat Berbasis Web", Menghasilkan sistem informasi geografis dengan visualisasi data spasial yang berisi informasi letak obyek-obyek wisata dan fasilitas penunjang wisata yang disajikan secara jelas kepada masyarakat sebagai promosi kabupaten gianyar.

\section{A. Sistem Informasi Geografis}

Banyak pengertian tentang sistem informasi geoagrafis, karena SIG sendiri terus berkembang. Selain itu SIG juga merupakan kajian ilmu yang relatif baru dibandingkan dengan kajian ilmu yang lain. Berikut beberapa definisi sistem informasi geografis, (Prahasta, 2002):

a. SIG adalah sistem komputer yang digunakan untuk memasukan (capturing), menyimpan, memeriksa, mengintegrasikan, memanipulasi, menganalisa, dan menampilkan datadata yang berhubungan dengan posisi-posisi di permukaan bumi.

b. SIG adalah kombinasi perangkat keras dan perangkat lunak komputer yang memungkinkan untuk mengelola (manage), menganalisa, memetakan, informasi spasial berikut atribut-atributnya (data deskriptif) dengan akurasi kartografi.

c. SIG adalah sistem yang berbasiskan komputer yang digunakan untuk menyimpan dan memanipulasi informasiinformasi geografi. SIG dirancang untuk mengumpulkan, menyimpan dan menganalisis obyek-obyek dan fenomena dimana lokasi geografi merupakan karakteristik yang penting atau kritis untuk dianalisis. Dengan demikian, SIG merupakan sistem komputer yang memiliki empat kemampuan berikut dalam menangani data yang bereferensi geografi: (a) Masukan, (b) Manajemen data (penyimpanan dan 
pemanggilan data), (c) Analisis dan manipulasi data, (d) Keluaran.

d. SIG adalah sistem yang terdiri dari perangkat keras, perangkat lunak, data, manusia (brainware), organisasi dan lembaga yang digunakan untuk mengumpulkan, menyimpan, menganalisa, dan menyebarkan informasiinformasi mengenai daerahdaerah di permukaan.

e. SIG adalah sistem komputer yang digunakan untuk memanipulasi data geografi. Sistem ini diimplementasikan dengan perangkat keras danperangkat lunak komputer yang berfungsi untuk: (a) Akusisi dan verifikasi data, (b) Kompilasi data, (c) Penyimpanan data, (d) Perubahan dan updating data, (e) Manajemen dan pertukaran data, (f) Manipulasi data, (g) Pemanggilan dan presentasi data, dan (h) Analisis data.

1. Subsistem Informasi Geografis

Menurut (Prahasta, 2005), Adapun subsistem dari Sistem Informasi Geografis adalah sebagai berikut:

1. Data Input: Subsistem ini bertugas untuk mengumpulkan dan mempersiapkan data spasial dan atribut dari berbagai sumber. Subsistem ini pula yang mempunyai tanggung jawab dalam mengkonversi atau menstransformasikan format-format datadata aslinya kedalam format yang dapat digunakan oleh SIG.

Ada dua macam data dasar geografi, yaitu data spasial dan data atribut:

a) Data spasial (keruangan), yaitu data yang menunjukkan ruang, lokasi atau tempattempat di permukaan bumi. Data spasial berasal dari peta analog, foto udara dan penginderaan jauh dalam bentuk cetak kertas.

b) Data atribut (deskriptis), yaitu data yang terdapat pada ruang atau tempat. Atribut menjelaskan suatu informasi. Data atribut diperoleh dari statistik, sensus, catatan lapangan dan tabular (data yang disimpan dalam bentuk tabel) dan lainnya. Data atribut dapat dilihat dari segi kualitas, misalnya kekuatan pohon. Dan dapat dilihat dari segi kuantitas, misalnya jumlah pohon.

2. Data Output: Subsistem ini menampilkan atau menghasilkan keluaran seluruh atau sebagian basisdata baik dalam bentuk softcopy maupun bentuk hardcopy seperti: tabel, grafik, peta, dan lainlain.
3. Data Management: Subsistem ini mengorganisir baik data spasial maupun data atribut kedalam sebuah basisdata sedemikian rupa sehingga mudah dipanggil, diupdate, dan diedit.

4. Data Manipulation dan Analysis: subsistem ini menentukan informasi-informasi yang dapat dihasilkan oleh SIG. Selain itu, subsistem ini juga melakukan manipulasi dan pemodelan data untuk menghasilkan informasi yang diharapkan. (Prahasta, 2002).

2. Manfaat Sistem Informasi Geografis

Fungsi SIG adalah mengingkatkan kemampuan menganalisis informasi spasial secara terpadu untuk dan pengambilan keputusan. SIG dapat memberikan informasi kepada pengambil keputusan untuk analisis dan penerapan database keruangan (Prahasta, 2002).

SIG mampu memberikan kemudahankemudahan yang diinginkan. Dengan SIG kita akan dimudahkan dalam melihat fenomena kebumian dengan perspektif yang lebih baik. SIG mampu mengakomodasi penyimpanan, pemrosesan, dan penayangan data spasial digital bahkan integrasi data yang beragam, muali dari citra satelit, foto udara, peta bahkan data statistik. SIG juga mengakomodasi dinamika data, pemutakhiran data yang akan menjadi lebih mudah.

\section{B. Pengertian Sistem}

Sistem pada dasarnya adalah sekelompok unsur yang erat hubungannya satu dengan yang lain, yang berfungsi bersama-sama untuk mencapai tujuan tertentu. Dari definisi ini dapat dirinci lebih lanjut pengertian sistem secara umum (Sutabri, 1998), yaitu sebagai berikut:

1. Setiap sistem terdiri dari unsur-unsur, unsurunsur suatu sistem terdiri dari subsistem yang lebih kecil, yang terdiri pula dari kelompok unsur yang membentuk subsistem tersebut.

2. Unsur-unsur tersebut merupakan bagian terpadau sistem yang bersangkutan. Unsurunsur sistem berhubungan erat satu dengan yang lain dan sifat serta kerja sama antarunsur sistem tersebut mempunyai bentuk tertentu.

3. Unsur sistem tersebut bekerja sama untuk mencapai tujuan sistem.

4. Suatu sistem merupakan bagian dari sistem yang lain yang lebih besar.

C. Model SPIRAL 
Model spiral (spiral model) adalah model proses software yang evolusioner yang merangkai sifat iteratif dari prototipe dengan cara kontrol dan aspek sistematis dari model sekuensial linier. Model ini berpotensi untuk pengembangan versi pertambahan software secara cepat.

Pengaturan resiko yang terbagi-bagi pada model spiral dapat memberikan strategi penentuan tertentu melihat dari resiko program dan efektivitas dari teknik penanganan resiko yang bersifat relatif. Selain itu pertimbangan yang dilakukan dalam manajemen resiko juga dapat menentukan ukuran waktu dan usaha khusus untuk aktifitas proyek tertentu misalnya perencanaan, manajemen konfigurasi, jaminan kualitas, verifikasi formal, dan pengujian. Misalnya pada spesifikasi berorientasi resiko dapat memberikan variasi ukuran ketuntasan dan formalitas tergantung tingkat resiko yang relatif, apakah terlalu banyak atau sedikit dalam melakukan spesifikasi. Hal yang terpenting dalam model spiral adalah pembahasan hasil dari proses pengembangan sistem dalam satu siklus spiral yang melibatkan orang atau organisasi yang penting dalam pengembangan perangkat lunak (Boehm, 1988).

D. Siklus Hidup Pengembangan Sistem

Proses pengembangan sistem mempunyai beberapa tahapan mulai dari sistem itu direncanakan sampai dengan sistem tersebut diterapkan, dioperasikan, dan dipelihara (kendall, 2003). Adapun tahap-tahap yang harus dilaksanakan secara sistematis dalam pengembangan sistem informasi adalah sebagai berikut :

1. Kebijakkan dan perencanaan sistem (System planning).

a. Permintaan untuk studi suatu sistem (request for a system studi).

b. Pengamatan/investigasi awal (initial investigation)

c. Studi kelayakan (feasibility study).

2. Analisa sistem (System analysis)

a. Mendefenisikan kembali masalah (redefine the problem).

b. Memahami sistem yang ada (understand the existing system).

c. Menentukan kebutuhan pemakai (determine user requirement).

d. Model logika dari pemecahan yang direkomendasi (logical model of the recommended solution).

3. Desain sistem (System design)

a. Desain ouput (output design).

b. Desain Input (input design).

c. Desain file (file design).
4. Implementasi sistem(System implementation)

a. Pembangunan sistem (system building).

b. Pengetesan (Testing).

c. Instalasi/konversi (installation/conversion).

d. Operasi (operation).

e. Kaji ulang setelah implementasi (postimplementation review).

5. Perawatan (Maintenance)

a. Menggunakan sistem

b. Audit Sistem

c. Memelihara Sistem

d. Perawatan dan peningkatan-peningkatan

\section{Metodologi Penelitian}

A. Teknik Pengumpulan Data

Metodologi penelitian ini bertujuan untuk mendukung dalam memperoleh informasi yang dibutuhkan dalam rangka mencapai tujuan penelitian. Teknik pengumpulan data yang benar akan menghasilkan hasil perbandingan dari apa yang diteliti sebelumnya. Untuk mendapatkan data yang lengkap dan akurat, pada tahap analisis dilakukan metode pengambilan data yang meliputi:

1. Metode Pengamatan (Observasi)

Observasi atau pengamatan merupakan teknik pengumpulan data dengan cara meneliti secara cermat terhadap masalah-masalah yang sedang diteliti. disini penulis melakukan pengamatan bagaimana cara kerja sistem pendataan dan pemetaan masyarakat penerima PKH sehingga diperoleh data yang sesuai dan dijadikan salah satu acuan dalam penelitian.

2. Metode Interview Atau Wawancara

Pengumpulan data dengan mengajukan pertanyaan-pertanyaan atau wawancara dengan para sumber atau pelaku yang terdapat dalam sistem. Dalam kasus ini pihak yang diwawancarai adalah para pendamping dan dinas-dinas terkait.

\section{B. Analisa Masalah}

Pada penelitian ini penulis menggunakan beberapa metode pengumpulan data metode yaitu metode studi pustaka, penulis mencari bahan yang berkaitan dengan tema yang diangkat. Pada metode observasi pengamatan secara langsung dengan pihak pegawai $\mathrm{PKH}$ Kecamatan Praya Tengah, Lombok Tengah, didapatkan kesimpulan permasalahan dalam sistem informasi pemetaan keluarga penerima manfaat (KPM) program keluarga harapan (PKH) yaitu penyebaran informasi dikarenakan kurangnya informasi lokasi dan data keluarga penerima manfaat (KPM) yang ada di Kecamatan Praya Tengah. 


\section{Metode Analisis}

Dalam metode analisa data, penulis menggunakan metode SWOT yang dimana prosesnya melibatkan penentuan tujuan yang spesifik dari spekulasi bisnis atau proyek dan mengidentifikasi factor internal dan eksternal yang mendukung dan yang tidak dalam mencapai tujuan tersebut.

E. Tahapan Model SPIRAL dalam Penelitian

Penelitian ini dilakukan dengan beberapa tahapan, agar mencapai tujuan yang direncanakan. Adapun tahapan model SPIRAL dalam penelitian ini dijelaskan pada gambar 3.1:

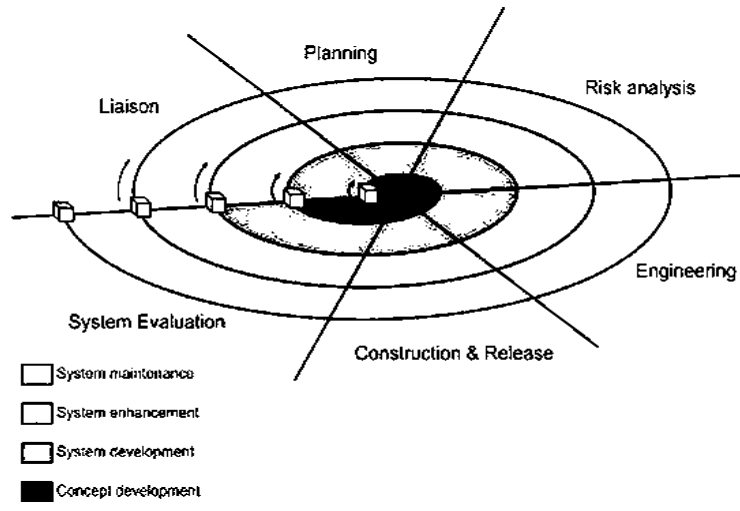

Gambar 3.1 Tahapan Model Spiral (Boehm, 1988)

1. Tahap Liason: pada tahap ini membangun komunikasi yang efektif di antara pengembangan dan pelanggan.

2. Tahap Planning (perencanaan): pada tahap ini ditentukan sumber-sumber informasi, batas waktu dan informasi-informasi yang dapat menjelaskan proyek.

3. Tahap Analisis Resiko: mendefinisikan resiko, menentukan apa saja yang menjadi resiko baik teknis maupun manajemen.

4. Tahap Rekayasa (engineering): pembuatan prototipe atau pembangunan satu atau lebih representasi dari aplikasi tersebut

5. Tahap Konstruksi dan Pelepasan (release): pada tahap ini dilakukan pembangunan perangkat lunak yang dimaksud, diuji, diinstal dan diberikan sokongan-sokongan tambahan untuk keberhasilan proyek.

6. Tahap Evaluasi: Pelanggan, pemakai, pengguna biasanya memberikan masukan berdasarkan hasil yang didapat dari tahap engineering dan instalasi.

\section{Hasil dan Pembahasan}

A. Analisis Sistem

Dari hasil anilisis pada kecamatan praya tengah mengenai pemetaan lokasi keluarga

ISSN. 2620-6900 (Online) 2620-6897 (Cetak) penerima manfaat (KPM) dapat dilihat pada flowmap yang sedang berjalan. Berikut gambaran dari proses pemetaan lokasi keluarga peneriaman manfaat (KPM) yang sedang berjalan di kecamatan praya tengah.

\section{B. Tujun Pembuatan Sistem}

Pembuatan sistem dapat berarti menyusun suatu sistem baru untuk membantu mengatasi permasalahan yang terjadi atau memperbaiki suatu sistem yang telah ada yang belum terkomputerisasi, karna adanya suatu permasalahan atau memenuhi instruksi yang diberikan oleh pendamping dan dinas-dinas terkait seperti BPS.

\section{Analisis Kebutuhan Sistem}

\section{Data Flow Diagram(DFD)}

Data flow diagram (DFD) merupakan gambaran grafis yang memperlihatkan aliran data dari sumbernya dalam objek kemudian melewati suatu proses yang mentransformasinya ke tujuan yang lain, yang ada pada objek lain. DFD memuat proses yang mentransformasi data, aliran data yang menggerakkan data, objek yang memproduksi serta mengkomsumsi data, serta data store yang menjadi tempat penyimpanan data.

Diagram Konteks

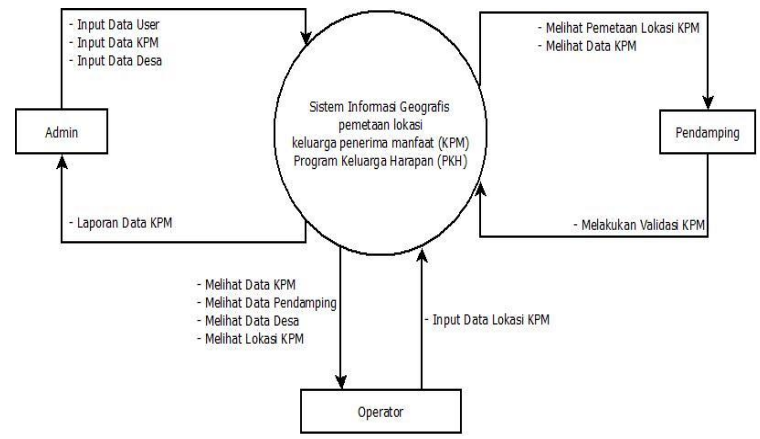

Gambar 4.1 Diagram Konteks 


\section{Diagram Level 1}

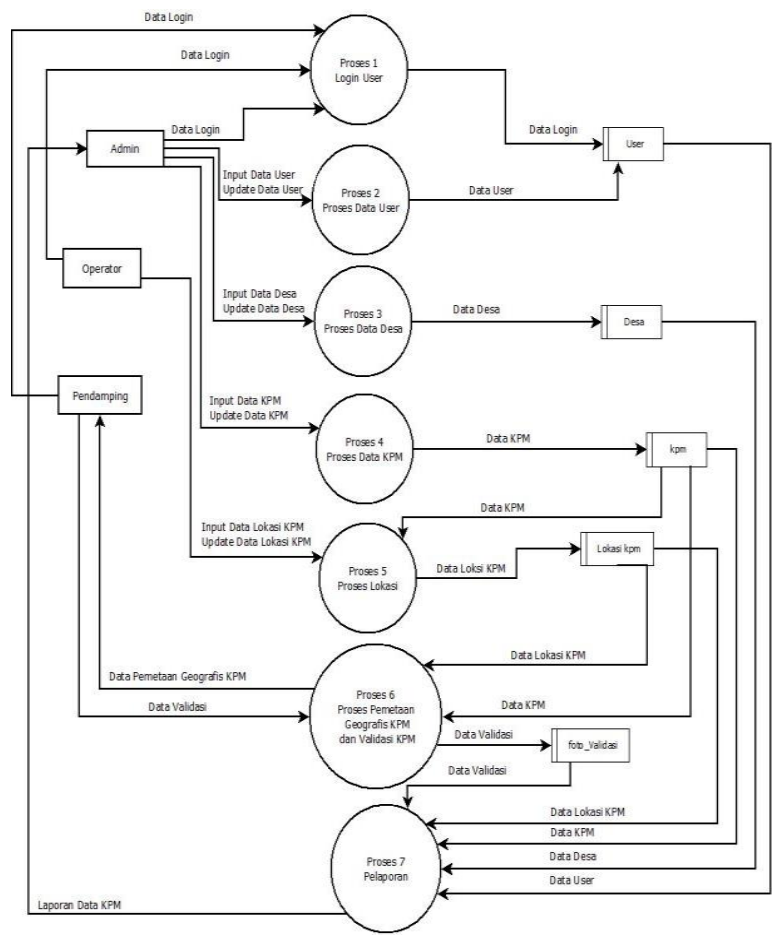

Gambar 4.2 Diagram Level 1

\section{Interface}

Perancangan antar muka (interface) merupakan proses desain suatu aplikasi. Proses desain sendiri terdiri dari beberapa tampilan yang menjadi keseluruhan aplikasi. Interface berperan sebagai media komunikasi yanng digunakan sebagai sarana berdialog antara program dengan user. Sistem yang akan dibangun diharapkan menyediakan interfaceyang menarik, mudah dipahami dan digunakan oleh user itu sendiri. Berikut adalah user interface dari sistem informasi geografis yang akan dirancang.

1) Menu Utama

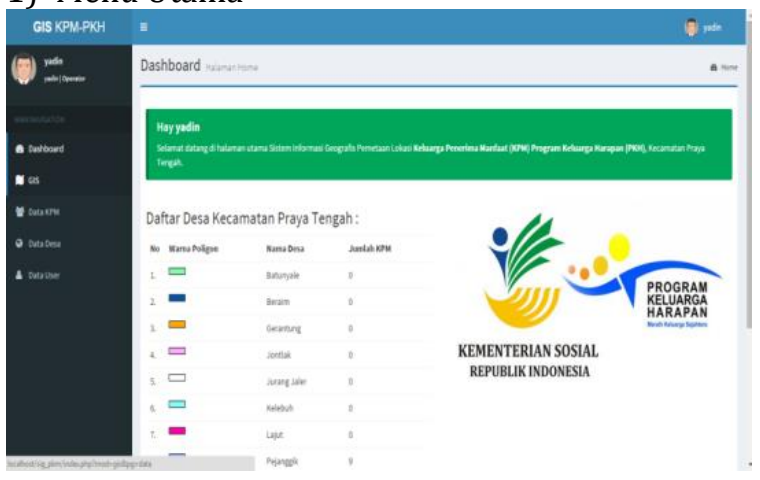

Gambar 4.3 halaman menu utama

\section{2) Extention Geoprocessing KPM}

Tampilan setelah dipetakan menggunakan Map ArcView maka terdapat marker KPM yang

ISSN. 2620-6900 (Online) 2620-6897 (Cetak) jika di klik akan muncul text box yang berisi data KPM dan button detail yang jika di klik akan menampilkan detail dari data KPM dan Data Validasi dari KPM.

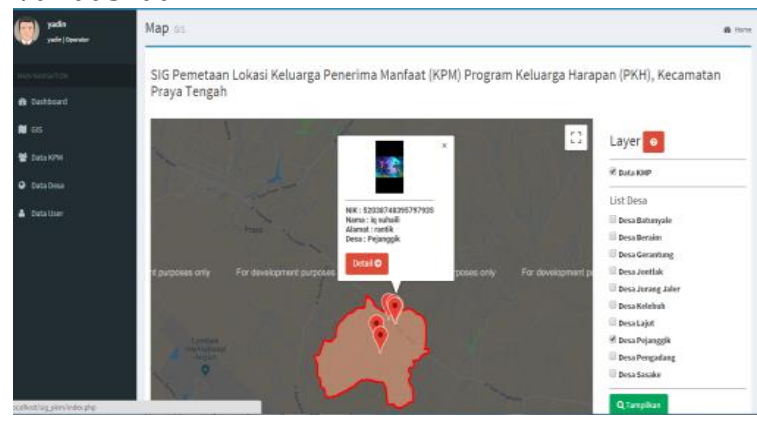

Gambar 4.4 Extention Geoprocessing KPM yang dipetakan

\section{Kesimpulan dan saran}

A. Kesimpulan

Kesimpulan yang didapat berdasarkan kajian dan tinjauan teori yang dimiliki serta dari hasil analisis dan perancangan sistem adalah:

Mempermudah pendamping luar kecamatan dan dinas terkait dalam menemukan lokasi dan detail keluarga penerima manfaat KPM yang berada di kecamatan praya tengah.

B. Saran

Saran yang dapat disampaikan oleh penulis adalah agar penelitian berikutnya bisa mengembangkan sistem ini lebih baik lagi, sehingga kekurangan yang ada bisa dilengkap atau diperbaiki. Saran yang dapat digunakan sebagai bahan pertimbangannya adalah sebagai berikut:

1. Lokasi pemetaan sistem ini masih dalam zona kecamatan, artinya sistem ini masih bisa dikembangkan ke zona atau wilayah yang lebih luas lagi.

2. Sistem ini masih pada tataran mencari titik lokasi KPM PKH. Peneliti selanjutnya dapat mengembangkan lagi sistem ini dengan menambahkan sistem validasi, pemutahiran data serta verifikasi data fasilitas kesehatan dan pendidikan.

\section{Daftar Pustaka:}

[1] Abdul Nizam Faisal (2016) "Sistem Informasi Geografis Berbasis Web Untuk Penyebaran Fasilitas Umum di Kabupaten Klaten".

[2] Alek wijaya, Eka Puji Agustini, Eko Nardo, (2018) "Sistem informasi geografis dalam pemetaan lahan gambut di kabupaten musi banyu asin". 
[3] Aloysius C. deo S. N, Kristoko Dwi Hartomo, frederik Samuel papilaya (2016) "Model Pemetaan Daerah Miskin Menggunakan Sistem Informasi Geografis".

[4] Al Fatta, H., 2007, Analisis Dan Perancangan Sistem Informasi. Andi. Yogyakarta.

[5] Faisal, Abul, (2011) "Sistem Informasi Geografis Berbasis Web Untuk Penyebaran Fasilitas Umum di Kabupaten Klaten, Skripsi, Sarjana Teknik Informatika, Fakultas Komunikasi dan Informatika, Universitas Muhammadiyah, Surakarta".

[6] Fadli, Sofiansyah. "Model Rapid Application Development Dalam Pengembangan Sistem Reservasi Dan Penyewaan Kamar Hotel". JIRE: Jurnal Informatika \& Rekayasa Elektronika. 1.1 (2018): 57-64.

[7] Fadli, Sofiansyah., Sunardi. "Perancangan Sistem Dengan Metode Waterfall Pada Apotek XYZ". MISI: Jurnal Manajemen Informatika dan Sistem Informasi. 1.2 (2018):29-35.

[8] Hidayat, Arif, (2010) "Rancang Bangun dan Desain Sistem Informasi Geografis Profil Daerah Kota Blitar Berbasis Web, Skripsi, Sarjana Teknik Informatika, UIN Maulana Malik Ibrahim, Malang".

[9] Jogiyanto, H., 2010, Analisis dan Desain Sistem Informasi, Edisi III, Andi, Yogyakarta.

[10] Imtihan, Khairul, Rabiatul Hadawiyah, and Hasyim Asyari-STMIK Lombok. "Sistem Informasi Penggajian Guru Honorer Menggunakan Konsep Agile Software Development dengan Metodologi Extreme Programming (XP) pada SMK Bangun Bangsa." IJNS-Indonesian Journal on Networking and Security 7.2 (2018).
[11] Nuraniah, M. (2012) "Sistem Informasi Geografis Berbasis Web Pemetaan Potensi Panas Bumi di Indonesia Menggunakan Google Maps. Jurnal Dasi, Vol. 13 No. 2 JUNI 2012".

[12] Nugroho, A., 2011, Perancangan Dan Implementasi Sistem Basis Data, Andi, Yogyakarta.

[13] Kadir, Abdul. 2003. "Pengenalan Sitem Informasi". Andi Offset, Yogyakarta.

[14] Kalaena, L. S., \& Bagye, W. (2018). Implementasi Network Attached Storage (NAS) Menggunakan Freenas Pada STMIK Lombok. Jurnal Manajemen Informatika dan Sistem Informasi, 1(1), 6-10.

[15] Boehm, B. W. 1988. A Spiral Model of Software Development and Enhancement, Computer, May, 61-72.

[16] Sunardi., Fadli, Sofiansyah. "Sistem Informasi Pengolahan Data Kelapa Sawit Berbasis Client-Server". MISI: Jurnal Manajemen Informatika dan Sistem Informasi. 1.2 (2018):23-28.

[17] Sunardi., Fadli, Sofiansyah. "Identifikasi Masalah Penerapan Metode Agile (Scrum) Pada Pengembangan Perangkat Lunak Di Perguruan Tinggi (Studi Kasus Universitas Nahdlatul Ulama Nusa Tenggara Barat)". MISI: Jurnal Manajemen Informatika dan Sistem Informasi. 1.2 (2018):14-18.

[18] Prayadi, Fendi, Khairul Imtihan, and Hairul Fahmi. "Sistem Informasi Monitoring Data Debit Daerah Irigasi Dengan Metode Pengukuran Debit Sesaat (Studi Kasus: Bendungan Batujai Kecamatan Praya Barat Kabupaten Lombok Tengah, NTB)." Jurnal Manajemen Informatika dan Sistem Informasi 1.1 (2018): 39-45. 